\title{
Creating British Global Leadership: The Liberal Trading Community from 1750 to 1792
}

\author{
by \\ Dr. Daniel J. Whiteneck \\ United States Air Force Academy \\ Department of Political Science \\ HQ USAFA/DFPS 2354 \\ Fairchild Drive, Suite 6L16 \\ USAF Academy, CO 80840-6258 \\ Email: WhiteneckDJ.DFPS@USAFA.AF.mil
}

Cite: Whiteneck, Dr. Daniel J. (1998). "Creating British Global Leadership: The Liberal Trading Community from 1750 to 1792." Journal of World-Systems Research http://jwsr.ucr.edu/ 4: $76-95$.

\begin{abstract}
:
This paper explores the process by which Great Britain rose to a position of global leadership in the 1800 s. It examines the critical period from 1750 to 1792 when Great Britain moved from global leadership based on colonial/mercantile power to leadership based on industrial/commercial power. I hypothesize that the roots of the Pax Britannica of 1815-1873 have their source in the emerging liberal trading community created by the British in the fifty years before the Revolutionary and Napoleonic Wars. This coalition of states was created around a dominant new idea (economic liberalism) based in the distribution of positive benefits from inclusion in the community, and intended to provide an innovative solution to the problems of international political economy created by the burgeoning industrial revolution. The community was created through the actions of successive British governments throughout the period, and served as the basis for the British-led coalitions which emerged victorious from the global wars of 1792 to 1815 . This case study helps answer important questions about how Great Britain was able to move from one period of global leadership to another, and on a more general level provides some insights into the role coalition-building plays in attaining and exercising global power.
\end{abstract}

1998 Dr. Daniel J. Whiteneck.

[Page 76]

Journal of World-Systems Research 
"Having each its own and distinct staple - having each that the other wanted; and not clashing in the great and leading lines of their respective riches, they were like two great traders in different branches, they might enter into a traffic which would prove mutually beneficial to them." (Aspinall and Smith, 1959:557)

This excerpt from William Pitt's speech to Parliament urging the passage of the Anglo-French Commercial Treaty of 1786 is the logical conclusion of nearly forty years of evolving British commercial policy with European states. The shift from a mercantile-based system to the modern liberal trading system of the 19 th Century was not to be completed until 1846 with the Peel government's repeal of the Corn Laws; however, the outlines of that system, including increasingly liberal duties and rights of merchants, reciprocity between trading partners, and the use of the 'most-favored-nation' principle as a basis for trading arrangements, can be glimpsed in the trading relations between Britain and her European partners from about 1750 to 1792.

This period coincided with the beginning of the industrial revolution, the waning of British mercantile power in the face of the American Revolution (in which the major powers of Europe aligned against Britain), the French Revolution, and ended with the outbreak of the global wars which lasted from 1792 to 1815 , in which the British-led coalitions defeated French attempts to displace Great Britain as the predominant global power.

An important question in the study of the history of the world political system and international relations is naturally asked: how did one state manage to succeed itself as the global leader in two distinct historical periods? Specifically, how did Great Britain manage the transition from global leadership during an era of "colonial-mercantilism" to leadership of a world system based on "commercial-capitalism"?

This paper examines a set of hypotheses that offers an explanation for that process. They are grounded in a long cycles approach (Modelski, 1978:214-235) to the functioning of the world system, which offers unique explanations for state behavior on two central points: 1) what is "world leadership" when compared to hegemony, and 2) an era of coalition creation preceding the phase of global warfare which lasted from 1792 to 1815.

[Page 77]

Journal of World-Systems Research

I analyze the actions of Great Britain during this period of world politics from a leadership versus hegemony perspective to place coalition creation within the context of functions of global leadership in the long cycle model. The leadership versus hegemony argument has been the subject of some contention between world-system theorists and it is important to my examination of Britain's creation of a liberal trading community.

David Rapkin's (1986 and 1989) four dimensions of leadership offer a good measuring post for testing British actions before the Revolutionary and Napoleonic Wars. 
Leadership in Rapkin's model has four characteristics; (1) "to guide", suggesting that leaders perform some task, service, or function, for the society, (2) "to influence the actions of others", the ability to alter the behavior of others through persuasion or coercion, (3) "to be in the first position", to be winning or have won some form of competition, and (4) "one whose example is followed", suggesting that leaders serve as role models for others to emulate.

I believe that we can measure the British-led trading community along each of these dimensions and arrive at a fuller picture of leadership or hegemony than that offered by other interpretations. Wallerstein's classic definition (1980) of hegemony, that "superiority consists of a situation in which one power is truly primus inter pares; that is, one power can largely impose its rules and wishes..." is not applied to Britain until after the wars which lasted from 1792-1815. Chase-Dunn, in Global Formation: Structures of the World-Economy, expands on Wallerstein's basic view of hegemony to include not only economic superiority, but also the use of military force and ideological hegemony to extend and consolidate the capitalist world-economy.

This idea of hegemony as coercion and consent (economic and military power coupled with mutual and overlapping interests in expanding historical capitalism) is compelling in some regards. Arrighi (1994) determines that all four states that he labels as "great powers" (p. 14) have "...networks of power and accumulation that enabled them to reorganize and control the world system within which they operated...", and that they were endowed with, "...ever-more extensive and complex organizational capabilities to control the social and political environment of capital accumulation on a world scale."

Arrighi's argument becomes stronger when he places this control outside of the traditional time frame of 1815-1873 and dates the British "long century" of control from the period of the American and Dutch Revolutions of the period 1770-1780.

There are however, important statements made by Arrighi when specifically focusing on the British cycle that return his concept of hegemony to a more coercive and exploitative model. He states that Britain was in the process of, "conquering (my italics) a worldencompassing commercial and territorial empire which gave its ruling groups and its capitalist class an unprecedented command over the world's human and natural resources." (Arrighi, 1994:218) Further on, he adds that Britain "turned to its own advantage" inter-state competition for mobile capital (Arrighi, 1994:218) and labels the British regime "cosmopolitan-imperial". He concludes that, "Under the Genoese regime, the world was 'discovered' and under the British it was 'conquered'." (Arrighi, 1994:219) 
Here we have two views of hegemony or leadership in the world system and we will return to them in the conclusion as we measure British actions throughout the period in question.

Conventional long cycles literature hypothesizes a core alliance between a current global leader and the rising global leader in the period before a global war. In this case there was no core alliance as Britain was the current leader of the world system under "colonialmercantilism" and would be the future leader of a system based around "commercialcapitalism". Instead of using the long cycle model of core alliances to explain coalition formation during the period in question, I examine the creation of a coalition of states by the future leader based on the provision of absolute economic gains. These gains are linked to a solution to the global problem of organizing the world system to respond to the political and economic consequences of the industrial revolution and its effects on the global economy and interstate relationships.

Community formation in this period can be manifested in many forms and is directly related to the dominant issues on the global agenda as framed by the global leader. The setting of the global agenda through the predominance of epistemic communities consisting of state and non-state actors is addressed in an earlier article in the Journal of World-Systems Research. (Whiteneck: 1996) That article examined the first stage of the long cycle process of agenda-setting in world politics. During the agenda-setting phase, world politics is characterized by political uncertainty and the framing of new issues. (see Goldstein and Keohane, Ideas and Foreign Policy: Beliefs, Institutions and Political Change, and Hall, The Political Power of Economic Ideas) The activities that collectively became known as the Industrial Revolution were beginning to tear at the underpinnings of the existing mercantile order of economics and interstate relations and new ideas for responding to the new challenges were dominated by a British-led nascent epistemic community. British merchants, scholars, diplomats, and government officials established a community throughout Europe that helped put economic liberalism on the global agenda.

There followed the formation of a trading community created by Great Britain that was an integral part of the global political and economic changes that arose around the developments of the industrial revolution, and the mechanism that facilitated the creation of that community was the use of the 'most favored nation' clause in a network of bilateral commercial treaties between Great Britain and other European states. There were a number of other commercial agreements between states within and outside Europe. This study focuses on the cases among the major powers in Europe in order to remove those cases based on unequal power relationships between states differ ently situated in the world economy and those cases between the major powers of Europe and the smaller quasi-states within Europe.

The period in question here, 1750 to 1792 , stands out because there was no core alliance in existence between Britain and a possible successor to leadership. The British were faced with organizing a winning coalition for the next phase of global competition without the benefit of a core alliance. It has been argued by realists, (Holsti: 1991, 
Schroeder: 1994, Kennedy: 1987) that the formation of the British-led coalitions during the Revolutionary and Napoleonic Wars was the result of the immediate security threats faced by the countries of Europe, and the French challenge to British domination of the seas. While it is unmistakable that some countries did face a grave threat to their independence, it is argued here that the strong commercial ties between Great Britain and its eventual allies served as a substantial base of support for the war-time coalitions.

Those ties had begun when Britain assumed a place as first-among-equals after the global wars of 1688-1713, and had been solidified when Britain, taking the lead in the industrial revolution, recognized the advantages to be gained in making more liberal and reciprocal trading arrangements with other European states.

This process created a positive incentive for those states to coalesce around Britain in a general continental conflict. These states had received tangible benefits from being involved in trade with Britain over the previous forty-plus years, and British ideas and policies about trade were evolving towards a general theory of liberalized trade among freer and more independent states. This was a powerful combination of positive incentives (even for the French merchants behind the 1786 treaty) that, when combined with French threats to security and trade (the Continental Blockade of 1807), made it logical for Britain to lead a series of coalitions to defeat the threats to new economic and security arrangements for Europe of Revolutionary and Napoleonic France.

[Page 79]

Journal of World-Systems Research

A world system is characterized by a high degree of uncertainty, especially in phases of agenda setting and coalition formation as new global problems are addressed and nations must make coalition decisions that will have long term consequences. Actors are more likely to form large, resourceful coalitions in a desire to belong to the most effective force possible. This desire is shaped by the tradition, ideology, and past experiences of likely coalition partners. (Groennings: 1970, Sabatier: 1988, Laver and Schofield: 1990, Higgott and Cooper: 1990) Groennings argued that coalition members have a greater tendency to join when the certainty of rewards and the ability to predict the actions of partners are increased. Sabatier challenges social scientists to examine the competing coalitions with different sets of value priorities and methods of achieving them within a larger social system.

The nation-states of Europe had many traditions and experiences with the British and with each other for centuries before the period in question. The continuing relationships in diplomacy, economics, and warfare left each state with long memories, and a knowledge of how important it was to belong to the strongest possible coalition in the case of renewed continental warfare.

The size and durability of these coalitions are supported by the desire of the actors to ensure the certainty and size of their expected rewards, as well as their ability to predict 
the actions of their partners. The rewards of belonging to the British trading community, as compared to exclusion, were great. The expectations of European states with regard to their relations with British governments were that such a relationship would not endanger the maintenance of their own national identities and aspirations to security and growth.

This paper proceeds with;

1. an examination of the foundation for Britain's rank as the reigning mercantile leader,

1. the effects of early industrialization on trade and trading philosophy,

1. the terms and advantages of trade relations in the period from 1740 to the $1770 \mathrm{~s}$,

1. the unique nature of the trading arrangements created by the British, and

1. concludes with the movements towards more liberal trade relations that occurred from 1783 to 1792 , moves that were interrupted by the global wars sparked by the actions of Revolutionary and Napoleonic France.

It draws on politics, diplomacy, and economics to create a picture of British leadership through a period of rapid change in the world economy. It uses trading statistics amassed from a number of sources, as well as an analysis of the treaties and commercial agreements that formed the heart of a new economic system for Britain, Europe, and the world at large. II

While Great Britain's relative leadership and predominance in the global economic order was not as great in the 18th Century as compared to the 19th Century, it is clear that the British had developed an elaborate trading network in the Atlantic, had penetrated and opened up the colonial markets of Spain and Portugal, and were still a major trading force on the continent, in addition to their vast colonial network in Asia and the Americas.

The 1703 Methuen Treaty was signed at Lisbon between Britain, the United Provinces, and Portugal. The first two members of the pact had merged their foreign policies since 1688 under the leadership of William of Orange, and were the two leading mercantile states of the time. The treaty granted each party's merchants personal privileges and freedoms of trade in the other's homeland and dominions and the right to carry on direct trade between the homelands and dominions. (Parry, 1969:407) The British advantages in trade with Portugal resulted in consistent trade surpluses for the British, which the Portuguese were able to finance through the export of gold from Brazil to England. This trade was so favorable to the British that by 1711 there were eighty British business concerns in Lisbon and Oporto. (Fisher, 1981:23-24) Britain's economy grew through the expansion of credit based on gold reserves and the promise of future profitable trade based on British advantages in the production and merchandising of textiles and manufactures for the Portuguese market. 
[Page 80]

Joumal of World-Systems Research

The 1713 treaty signed at Madrid between Spain and Great Britain was another indicator of British ascendancy. Spain, when under French rule during the reign of Louis XIV, had imposed a $15 \%$ surcharge on British imports, over and above the import duties determined by the 1667 commercial treaty between the two parties. Spain now conceded "...to the English nation all the other exemptions, advantages, rights, and privileges, which have been conceded and not revoked, or which shall be conceded in the future to the subjects of France or to any other nation...". (Parry, 1969:462) With such an arrangement, their superior merchant fleet, better financing, and growing textile industry, the British were able to undercut competitors operating under the same trading standards.

The treaty of commerce between Sicily and Great Britain signed at Utrecht in 1713 was another indication of how the power of the British fleet and the position established in Portugal were paying off. This treaty mirrored the treaties with Spain and Portugal: the same language was used to set up the relations between the states, "...enjoy all those rights, privileges, liberties, and entire security, as to their persons, goods, ships, seamen, trade, and navigation...". (Parry, 1969:401) There was again similar language on the treatment of British goods as compared to the goods of other European states: "...if hitherto any more favourable privileges have been granted, or shall hereafter be granted, to the merchants of any other foreign nation, any way relating to the persons of the traders, their ships, goods, duties, or the business of merchandising, the British merchants shall likewise in all respects, and in fullest manner, enjoy the same...". (Parry, 1969:401)

The British had assumed the first place among the states of Europe from the Dutch, who had been exhausted by the wars against France. London replaced Antwerp as the commercial and financial capital of the world economy, developing a sophisticated trade network with Hamburg, Lisbon and Oporto, Sicily and Naples, Riga and St. Petersburg, and numerous entrepots in Asia.

The French realized their status as second to the British. F. Crouzet argued that the French observers in the $1700 \mathrm{~s}$, "...singled out, as the key to England's wealth and power, her foreign trade...". The French observers also noted that the British, even in the years after the wars of 1688-1713, enjoyed the free exportation of goods, low or duty-free imports of raw materials for textiles and manufactures, along with the absence of internal customs (Crouzet, 1981:63).

The British added to their advantageous position by being the lead state in harnessing the innovations and resulting changes in production that would collectively come to be known as the Industrial Revolution. This process, begun around the middle of the 18th Century, would enable the British to grab a competitive advantage in the leading sectors of the world economy. They would, therefore, be able to produce and sell goods more cheaply than their competitors, while paying the same duties as other states. It also meant 
that the new industries would require a constant influx of raw materials. The incentive of lower duties to promote necessary imports could result in agreements with other states to lower their tariffs in the interest of promoting mutually beneficial exports.

Between 1740 and 1765, the British government allowed import duty exemptions and reductions for Irish woolens, linen yarns, and raw silk. These products alone accounted for $50 \%$ of the total value of raw material imports for the decade after the last restrictions were lifted (Davis, 1966:314). This growth in imports went to fuel the textile industry which spearheaded British industrial growth in the forty years between 1740 and 1780 .

Paul Langford (1989) lays out some of the significant changes of the era. He includes the reductions in the interest rate during 1750 , the publication of the first Universal Dictionary of Trade and Commerce in 1751, the founding of the Levant and East India Companies in 1744 and 1764, respectively, and the Free Ports Act of 1766.

[Page 81]

Journal of World-Systems Research

This increasing domestic activity was accompanied by political and economic philosophies that invited other European states into closer economic and political relations for the purposes of increasing wealth and promoting freer enterprise throughout the continent.

John Campbell, a contemporary commentator, authored a book titled, The Present State of Europe, in which he set out a list of principles which were to be guides for British foreign policy in 1750. Excerpts from the book should be quoted in depth:

- "...the Interest and the Commerce of the British Empire are so inseparably united, that they may be very well considered as one and the same. Whatever therefore assists, promotes, and extends our Commerce, is consistent with our Interest, and what-ever weakens, impairs, or circumscribes it, is repugnant thereto."

"The first point dictated by our Interest, is the maintaining of others in their rights, or to make use of a more known term, to support the independency of the Powers of Europe; because the engrossing, subjecting, or subduing of several countries under one Potentate, naturally and even necessarily contributes to lessen the number of inhabitants, to extinguish industry amongst them, and consequently to enfeeble and impoverish them."

"We ought likewise to be ready to assist any Nation that is unjustly attacked, or in any Danger of being oppressed, that it may be seen we are true lovers of Freedom, and as are unwilling to behold the Necks of others put under the Yoke, as to submit our own." 
"It may sometimes happen, that a strict Compliance with these Rules will interfere with some Branch or other of our Commerce; neither in such a Case must that be regarded, for it is not this or that particular Branch of Commerce, which coincides with the general Interest of this Nation, but the whole Circle of our Commerce; and therefore there is nothing absurd or contradictory in affirming, that the Whole must take place of a Part."

These quotes from Campbell are symbolic of a growing opinion in England that, while all could see that trade had been the cornerstone of the mercantile empire, trade with other European states could be handled on the basis of mutual benefit to free and independent states. This is forty years prior to the outbreak of the general wars of Europe that raged from 1792 to 1815 , but here the outlines of the British-led coalitions are apparent, as is the importance of economic interaction as a motivation for the coalition building process.

\section{III}

Along with the industrial revolution came significant advances in trade relations between Britain and the other major European states. The treaty with Portugal (see above) was updated and revised in 1743, a new treaty was signed with Spain in 1750, and commercial agreements were reached with Russia and Sweden in 1766. The conflicts surrounding the American Revolution would temporarily halt these advances, but there were renewed trade negotiations after 1783, with the climax coming at the signing of the Anglo-French Commercial Treaty of 1786 . These treaties and negotiations were remarkable for their similarity and systematic inclusion of key points and phrases that, in more complex and specialized forms, would be used in liberal trading arrangements for the next two centuries.

The Treaty of Commerce between Great Britain and Spain signed in 1750 was notable for three components: Article IV rolled back duties to the levels that had existed in the $1600 \mathrm{~s}$ during the reign of Charles II (this was important for the growing exports of British woolens and manufactures, and Spanish exports of wines and oils); Article VII contained the by now familiar reciprocity standard for merchants operating in both countries, along with the first use of a phrase used ever since as a linchpin for liberalized trade, "...British merchants shall be treated in Spain, in the same manner as the most favored nation, and consequently, no nation shall pay less duties upon goods...". (Parry, 1969:81) Thus we see that the treaty contained in rudimentary form, the principle elements of many future agreements; lower duties, reciprocity, and the idea of 'most favored nation' status (which presupposes a community of equal members and a group of nations that are excluded, and thus denied the benefits of improved trade relations). These elements were to be refined and perfected by liberal states down to the current practices of the democratic capitalist community of states.

[Page 82]

Journal of World-Systems Research 
The impact of these standards can be seen in the treaties with Sweden and Russia signed in 1766. Both treaties serve to demonstrate how comparatively liberal agreements were favored by the British and were mutually beneficial to her trading partners.

The Swedish treaty contained the standard clauses on reciprocity and 'most favored nation' status, but it did not reduce the duties that the Swedes placed on imports. Not only that, but it contained exceptions that allowed France to import goods into Sweden at lower duties than other states as a result of a separate 1741 treaty. (Parry, 1969:77) This was unfortunate for the Swedes because they possessed the timber and iron that the British were so very anxious to import. They believed that because, for the previous fifty years the British Navy had bought its mast timbers from Swedish-controlled Scandinavia, this condition would continue despite the changing trading relationships of the second half of the 1700s. (Astrom, 1981:81)

Faced with this situation, the British were to shift the focus of the Baltic trade to the newly emergent Russian state. This shift would have benefits for the Russians and the British for years. The 1766 treaty between the two nations had a long history of development, going back to the establishment of the Muscovy Trading Company in 1553 and the actions of Peter the Great in opening up Russia to the West in 1698. It was in 1698 that Peter, then only a twenty-six year old Tsar, traveled across Europe to Holland and England to explore the strengthening of Russian trade, shipbuilding, and industry. The trip paid off handsomely, for by 1750 the Russians were producing 35,000 tons of iron per year, up from 16,000 tons per year in 1718. (Federov, 1979:142)

The 1766 treaty superseded a 1743 agreement by expanding it into the standard form seen above. The essential principle of the treaty, formulated in the first clauses, was that of 'most favored nation' treatment. There were also clauses on reciprocity, the lowering of duties on woolens and manufactures, and the reduction of tariffs on Russian iron and timber. The result was that a trade volume of $1,133,000$ pounds sterling in 1765 would rise to a volume of $3,500,000$ pounds sterling by 1800 . This increase would vault Russia into first place among the importers of goods into Great Britain. (Federov, 1979:142)

The British manufactures flowing back into Russia and the development of Russian capitalists helped spark the Russians' own revolution. These new, smaller-scale capitalists (as compared to the landed nobility) wanted more liberal trade, more banks for capital development, and the ability to establish factories anywhere in Russia, just like their British trading partners.

The Russian attitude was summed up by Empress Elizabeth at this time; "...it is better to do business with the British who demand little of us and whose Commercial Wants render them in some measure dependent on us... whose Account is in gain, and not in Conquest...". (Clendenning, 1979:151) The result was a 90\% reduction in tariffs on woolen imports and the lifting of export restriction on British merchants. The British responded by recognizing the rights and privileges of the growing Russian merchant fleet and the exemption of Russian raw linen yarn from import duties. The Russians gained a stronger merchant class and assured sales of Russian goods thanks to the low duties. The 
British secured their needed raw materials at favorable prices and increased their export earnings. For example, the export of woolens to Russia went up by $50 \%$ from the $1760 \mathrm{~s}$ to the 1770s. (Clendenning, 1979:151)

That the new arrangements of liberality and reciprocity left the Swedes out of the community benefits can be measured by the exports of timber from Russia and Sweden to Britain in the decade from 1784 to 1793 . In that period Russia exported one million dozen boards from Viborg, while the Swedes shipped out 165,000 dozen boards from Swedish Finland. (Astrom, 1981:87) The 1766 treaty demonstrated; "...the extent to which Britain, as Russia's 'natural ally' was prepared to abandon diplomatic initiatives in Sweden, Poland, or Turkey, if given the alternative of commercial success." (Clendenning, 1979:156)

The Russian-British relationship became so strong and mutually successful that Napoleon's imposition of the Continental Blockade of 1806 disrupted the Russian economy, with the result that the Anglo-Russian coalition formed in response became the heart of the last, and ultimately successful coalition against Napoleon in those wars.

[Page 83]

Journal of World-Systems Research

\section{IV}

The direction of British trade with Europe was influenced by the arrangements Britain had made in the Baltic, on the Iberian Peninsula, the Mediterranean, and by her close ties with the Netherlands carried over from the previous century. Table 1: British Trade Balances 1771

\begin{tabular}{|l|l|l|l|}
\hline Balance of Trade & Favorable & Even & Unfavorable \\
\hline \hline Country & $\begin{array}{l}\text { Spain/Portugal } \\
\text { Denmark/Norway }\end{array}$ & Prussia & Sweden \\
& $\begin{array}{l}\text { Austrian Neth. } \\
\text { Germany }\end{array}$ & Poland & Russia \\
& Holland & Italian States & \\
& France & & \\
\hline
\end{tabular}

(Source: Aspinall and Smith,1957:489) 
Table 1 demonstrates that the British had moved away from the strict mercantile principle of striving for trade surpluses with its rivals by building up their own internal mercantile colonial empire and exporting manufactured surpluses to other European states. It shows that they had a trade surplus with only seven out of twelve European trading partners. Liberalized arrangements had been made with Spain, Portugal, Russia, Holland, the Austrian Netherlands, and the Italian States.

[Page 84]

Joumal of World-Systems Research

Table 2: Destinations of British Exports and Imports (Yearly Averages in Pounds)

\begin{tabular}{|l|l|l|l|}
\hline Country & $1751-1755$ & $1786-1790$ & $\%$ Change \\
\hline Austrian Neth. & To 450,000 & 893,000 & +198 \\
& From 89,000 & 134,000 & +50 \\
\hline France & To 458,000 & 979,000 & +214 \\
\hline German States & From 57,000 & 479,000 & +840 \\
\hline To $1,351,000$ & $1,457,000$ & +7 \\
\hline Holland & From 690,000 & 476,000 & -31 \\
\hline Poland/Prussia & To $2,786,000$ & $1,208,000$ & -57 \\
\hline Russia & From 306,000 & 376,000 & +23 \\
\hline Sweden & From 277,000 & 453,000 & +36 \\
\hline & To 17,000 & 61,000 & +63 \\
\hline & From 194,000 & 228,000 & +360 \\
\hline
\end{tabular}




\begin{tabular}{|l|l|l|l|}
\hline Portugal & To $1,098,000$ & 622,000 & -43 \\
& From 272,000 & 597,000 & +218 \\
\hline Spain & To $1,038,000$ & 633,000 & -42 \\
& From 405,000 & 683,000 & +68 \\
\hline Italy & To 252,000 & 729,000 & +289 \\
\hline Turkey & From 590,000 & 747,000 & +26 \\
\hline & To 123,000 & 102,000 & -18 \\
\hline
\end{tabular}

(Source: Aspinall and Smith, 1957:491)

Looking at the changes in trade over time offers support for the idea that the British were creating a series of bilateral relationships which were shifting the trade patterns that had been important during the era of strict mercantile competition. Trade volumes and balances were declining or stagnant with established states like Holland, the German states, Portugal and Spain, while trade with the Austrians, French, Russians, and Italians was expanding greatly. The gold and silver based economies of the mercantile period were now giving way to the commodity and finished goods markets of the beginning of the industrial revolution. Table 3: Changes in Overall British Trade Flows

\begin{tabular}{|l|l|l|}
\hline Year & $1713-1750$ & $1750-1780$ \\
\hline \hline Value of Exports & high $12,599,122$ & high $19,018,481$ \\
low $7,696,573$ & low $12,253,890$ \\
avg. $9,422,039$ & avg. $15,636,185$ \\
\hline Balance of Trade & high $+6,521,964$ & high $+7,239,133$ \\
low $+1,904,151$ & low $+1,379,653$ \\
avg. $+3,807,739$ & avg. $+4,309,393$ \\
\hline Surplus as a & $41 \%$ & $28 \%$ \\
\hline
\end{tabular}




\begin{tabular}{|l|l|l|}
\hline$\%$ of Exports & & \\
\hline
\end{tabular}

(Source: Schumpeter, 1960:17) [Page 85]

Journal of World-Systems Research

Table 3 illustrates that the overall volume of British trade was increasing rapidly, as exports were up by $65 \%$, while at the same time, surpluses fell in relative terms (only rising by $14 \%$ ). The old mercantile system had operated in such a manner that increases in exports were treated as the acme of economic performance because it meant that a favorable balance of trade would result in a net inflow of bullion into the coffers of the state. What the thirty years from 1750 to 1780 show is that while Britain was increasing its exports to European states, at the same time, it was increasing its imports from these states at an even higher rate. The British wealth earned in export trade of woolens and manufactures was being used to purchase foreign goods and raw materials to further the advance of the industrial revolution. The statistics on increases in labor productivity and industrial sector growth cited above show that the British were investing in new imports in such a way that they were able to shift leading economic sectors, maintain their industrial advantages, and prepare for another century of economic leadership.

Table 4: British Industrial Segment Growth ,1780-1790

\begin{tabular}{|l|l|l|l|l|}
\hline Change & Rapid Gain & Slow Gain & Stationary & Declining \\
\hline \hline Industry & Iron & Steel & Lead & Tin \\
& Glass & Paper & Hemp & Flax \\
& Porcelain & Silks & Cotton & Leather \\
& & Manufactures & Woolens & \\
\hline
\end{tabular}

(Source: Aspinall and Smith, 1957:491)

The above figures coincide with the accounts of trade compiled in the 1770s which focus on the importance of woolens and manufactures as the key exports to Holland, Portugal, Spain, and Russia. Woolens were still the lead export to the German States, Prussia, Italy, the Levant and Turkey, and Sweden, while imports from the Baltic (iron, copper, and 
naval stores), Holland (capital and spices), Iberia and the Mediterranean (wines, oils, silks, and gold) were used to finance the shift from woolens to manufactures.

This was the state of affairs at the time of the American Revolution, a time when this trade network along with the British security framework, which were based on its ability to form coalitions with continental partners, would suffer serious setbacks. These setbacks would be combined with Adam Smith's intellectual assault on mercantilism and the realization by other states that the British idea of direct trade between European countries and overseas colonies of other states could be of benefit to more than just the British. It would take the calamities in the wars of 1776 to 1783 , before the British would resume the process that had been started fifty years before. The inspiration of Lord Shelbourne, the leadership of William Pitt, and the efforts of British political economists and merchants would push trade liberalization to new levels in the decade before the outbreak of the Revolutionary and Napoleonic Wars in 1792.

Britain's response to this crisis has been characterized by George Modelski as, "... a series of spectacular innovations in industry, trade, and economic policy that one century later came to be referred to as the Industrial Revolution." "...Her policy shifted away from colonial monopolies and protected markets to a self-confident assertion of free trade; her assurance was derived from the great productivity of her new factories. It was a dramatic turn-away from trade empires in the Portuguese-Spanish mode, towards an empire of free trade, still dependent on an overarching political framework but qualitatively different in allowing for more choice and flexibility." (Modelski, 1987:85)

The new British attitude was summed up by Lord Shelbourne, as he defended the peace treaty that had been signed by the Americans, the French, and the British in 1783, when he told Parliament that, "...we prefer trade to dominion...". Shelbourne went on; "...we shewed (sic) to the Americans our sincere love and fair intentions, in dividing the little bit of trade which nature had laid at their doors; and telling them that we desired to live with them in communion of benefits, and in the sincerity of friendship...". (Modelski, 1988:230) Shelbourne paid for his foresight and devotion to a new principle of freer trade by losing his position as Prime Minister; but his successor, William Pitt, carried the same ideas of liberality and reciprocity into the next decade.

[Page 86]

Journal of World-Systems Research

\section{$\mathbf{V}$}

In 1784 the British Government and British merchants faced an economic crisis that required bold new moves; they needed not a mercan tile system of high tariffs to protect domestic industries, but tariffs designed to raise revenues to carry out government functions. 
As Prime Minister, William Pitt moved personally to assume control of this critical area of economic policy. In 1784 he abolished the Committee on Trade, and established a new Board of Trade. He put himself and Lord Grenville, a committed free trader, on the panel. This group was to have ninety-nine meetings in its first year of operation. Grenville was in attendance at all of the meetings, and Pitt only missed six of them. This group's tasks included; guiding negotiations with France, preparing new arrangements with existing trade partners, initiating legislation on trade matters, and giving advice to other departments of government on matters that would effect British trade. (Harlow, $1964: 241)$

The extensive trade negotiations which took place over the next ten years have been carefully described by John Ehrman in his book, The British Government and Commercial Negotiations with Europe 1783-179, and will be briefly sketched here. Much of the information he provides gives the reader a glimpse at the trading relations that were to revolve around Britain in the years after 1815 , relations that might have come sooner had it not been for the global war that lasted from 1792 to 1815 . I will move past Ehrman's study of the negotiations to examine how the treaties and agreements that were the products of these negotiations continued the process of coalition building which was at the heart of Britain's rise to political and economic leadership.

Negotiations for new commercial agreements with Portugal and Spain began in 1786. The British argued for full reciprocity on merchant freedoms and treatment, and for duties at the same level as those charged on imports from other European states. The British wanted duties of between $12 \%$ and $23 \%$, levels equivalent to those of the 1703 Methuen Treaty. (Ehrman, 1962:15) In return, the British offered to place, not just wines and sherry, but tobacco, rice, and other goods from the Iberian colonies in the familiar 'most favored nation' status. Negotiators for the parties in both negotiations reached agreements on MFN status, reciprocity for merchants and shipping, and tariff reductions to rates of 12\%. (Ehrman, 1962:90)

The negotiations were suspended and eventually destroyed by internal politics in both Portugal and Spain which led to changes in governments, changes in ministers, and internal disruptions which put off foreign policy decisions. These were to be fatal to the negotiations because they lasted until war broke out in Europe in 1792-93.

Negotiations with the Ottoman Empire at the other end of the Mediterranean had a better outcome. During the 1700s the Russians and the Turks had fought many wars over conflicting claims in the Balkans and the Black Sea, and for control over access to the Mediterranean. After the Anglo-Russian Treaty of 1766, the French had received preferential treatment in Turkey as a counterweight to British influence in Russia.

The growing power of the Levant Company (founded in 1744) was about to pay formal dividends to the British. In spite of French tariff advantages, British goods (cloth, muslins, dyes, spices, watches and clocks, and small manufactures) were doing record business in the Ottoman Empire by the 1780s, thanks to the benefits of the British industrial comparative advantage. Utilizing their connections with domestic merchants, 
and offering favorable terms for the importation of Turkish cotton, the British were able to negotiate a 1784 agreement. Henceforth, British goods were to be given 'most favored nation' status, placing them on an equal footing with the French. By 1786 , the records set in the early 1780 s had all been broken, as British trade with the Ottoman Empire went forward together with British trade to the Russian Empire. (Ehrman, 1962:143)

British efforts in the Austrian Netherlands at liberalizing trade also moved forward in the 1780s. The Austrians had used the area (what is now Belgium) as a gateway to the seas. The 1748 Treaty of Aix-la-Chapelle had kept the area open to trade, created a free port at Ostend to handle the trade of the region, and exempted the area from the trade restrictions applicable to Austria, Hungary, Galicia, and Hapsburg Germany. The treaty had also allowed the British trading rights on a par with the Dutch, who had long been dominant in the region. (Parry, 1969:101)

[Page 87]

Journal of World-Systems Research

In the 1780s the tariffs that applied in the Austrian Netherlands were higher than those which were being negotiated in the rest of Europe, so the British sought a change in their structure. They proposed in 1790 that the tariff schedule be the same as that applied in the Anglo-French Commercial Treaty of 1786 , and that the 'most favored nation' principle be applied to all imports from the region. (Ehrman, 1962:147) These negotiations were derailed by the security interests that came to the fore with the actions of Revolutionary France in 1792.

In contrast to the above negotiations and agreements were the situations surrounding the trading relationships with Sweden and Prussia. Both states erected systems of protection for their domestic products and for the strict control of what they deemed to be vital raw material exports. As an example, Sweden's import duties on goods shipped in foreign hulls was set at $40 \%$, while Frederick the Great had restricted exports of Prussian timber. It has already been noted how Sweden's actions in the 1760s had a negative effect on the reciprocity principle which was an important part of the trading community, and now Prussia took a similar path. (Hubatsch, 1973:115)

The greatest risk of the changing trading policies of these years had to be the AngloFrench Commercial Treaty of 1786 . It marked a significant departure from traditional British foreign policy; for the previous one hundred years Britain and France had been intense rivals. They had offered the world competing models of political organization (parliamentary democracy and absolute monarchy), and interstate relations among the great powers of Europe and the world through the wars of Louis XIV. The British had emerged victorious and set about establishing the alliance network, colonial empire, and mercantile economy that were to characterize her leadership from 1713 to about 1750 . 
In 1783 the rivalry between France and Britain was so intense that each used severe trade restrictions to hamper the war-making capacities of the other. The only trade that was carried on between the two states was by smuggling. This was a growing business because each state produced goods that the other's citizens were willing to pay high prices for. The economic costs from lost revenue and lost productivity were damaging to the Pitt government, eager as it was to rebuild after the calamity of the American Revolution. Pitt, a disciple of Adam Smith, was determined to remedy this situation by moving the British and the French towards an agreement which he was sure would reduce the tensions through the improvement of economic conditions on both sides.

The negotiations which were to last from 1784 to 1786 resulted in a revolutionary treaty. "The commercial treaty was based on principles that broke away from all the old doctrines of mercantilism". (Malcolm-Smith, 1937:219) Pitt focused on the trade in French wines and silks and British textiles and manufactures as the basis for the agreement. Import duties were reduced to levels of between $10 \%$ and $12 \%$, reciprocal rights and privileges for merchants were established and guaranteed, and the principle of 'most favored nation' was applied on the most general terms to goods. (Parry, 1969:223)

The debate in Parliament on the adoption of the treaty offers a view into the distance traveled by British trade policy in the previous forty-plus years as it moved away from strict mercantilism. Pitt stated that; "...by promoting habits of friendly intercourse, and of mutual benefit, while it invigorated the resources of Britain, it made it less likely that she should have occasion to call forth those resources". The treaty gave, "... a better chance for the preservation of harmony between them, while so far from weakening, it strengthened the sinews of war...". Pitt concluded; "...to procure this, we certainly ought not to scruple to give liberal conditions. We ought not to hesitate, because this which must be so greatly advantageous to us must also have its benefit for them". (Aspinall and Sinith, 1959:559)

The benefits from the treaty were quickly noted: increases in imports and exports between the two states along with increases in the revenues, and at the same time duties were falling. The increases are supported by the data in Table 2 which showed a $214 \%$ rise in the value of British exports when compared to the period thirty years earlier, along with an $840 \%$ rise in the value of French exports to Britain. The benefits to France were concentrated in the Loire Valley and Bordeaux wine regions and the silk communities along the coast. This is backed by the findings of Patrick O'Brien and Caglar Keyder (1978) who argue that the trade between the two states was based on the comparative advantages each had developed in the past. In the case of France the exporters who were ready to take advantage of the new situation were those industries which were used to serving people with higher incomes and a concern for quality and style. In these areas the strength of the French liberals was great, and would come into conflict with the interests of the French peasantry and urban working classes in 1792. It would be the victory of the Jacobins in 1792 that would signal the success of nationalism and radicalism and the repudiation of the commercial agreement that had shown such promise in the first years of its existence. 


\section{VI}

Is there a detectable pattern in the negotiations and agreements that characterized British trading relations with other European states? Can it lead to the conclusion that there was a systematic, concerted, and sustained effort by the British to create a relatively more liberal trading community that would revolve around British lead industries, but would also have benefits for each of the trading partners? Or is it merely the result of a general trend toward liberalized trade among all major powers, without signifying anything about global leadership? Did this trading community put into place a system that was threatened by the actions of Revolutionary and Napoleonic France, helping to shape the coalitions that Britain led to victory in the wars from 1792 to 1815 ? Table 5: Commercial Agreements 1740-1792, Great Britain-European States

\begin{tabular}{|l|l|l|l|l|}
\hline Nation & Treaty? & MFN Status & Reciprocity & Low Duties \\
\hline Spain & Yes & Yes & Yes & Yes \\
Portugal & Yes & Yes & Yes & Yes \\
Russia & Yes & Yes & Yes & Yes \\
$\begin{array}{l}\text { Austrian } \\
\text { Neth }\end{array}$ & Yes & Yes & No & Yes \\
Sweden & Yes & Yes & Yes & No \\
Prussia & No & No & No & No \\
$\begin{array}{l}\text { Ottoman } \\
\text { Emp. }\end{array}$ & Yes & Yes & Yes & Yes \\
France & & Yes & Yes & Yes \\
\hline
\end{tabular}

[Page 89]

Journal of World-Systems Research 
Table 5 demonstrates that the British were very successful in setting up a network of trade in the fifty years before the outbreak of war in 1792. Over that period there were agreements with the other major political and economic powers of Europe. These agreements were sometimes formal treaties and sometimes revisions and conventions to earlier treaties. Six of those arrangements contained specific provisions for treating goods, merchants, and shipping with the MFN status. Five of the agreements had particular guarantees for the protections of rights, privileges, and immunities of merchants which were of such importance in the new industrial age. Five of the agreements specifically lowered duties on imports -- not blanket reductions to be sure, but reductions focused certainly on the goods that were deemed to be the most important of the period. For the British this meant reductions on duties for woolens and small manufactures, while for her partners this meant reductions on those goods being shipped to Britain to fuel the Industrial Revolution or satisfy the demands of a growing British consumer class. This trading community accounted for $54 \%$ of world trade and $73 \%$ of European trade, (Rostow, 1975:115) figures that argue for assessing the British as the preeminent economic, political, and diplomatic leader of the world system before the start of the global war of 1792 to 1815 , rather than the end of that war.

Were these economic arrangements linked to the security alignments that characterized the Revolutionary and Napoleonic Wars? Five nations (Spain, Portugal, Russia, the Ottoman Empire, and France) met all four of the requirements for inclusion in the trading community. Of these five, four were to be British allies in the wars against the fifth, France.

Two nations (Sweden and the Austrian Netherlands) met three of the four requirements. Sweden had effectively shut itself out of the trading community after 1766 through its adoption of high tariffs. Sweden could sign a treaty putting into effect the reciprocity norms and the 'most favored nation' status, but it could not expand these into a larger relationship so long as its duties discouraged British manufactured imports and its own timber exports. The Austrian Netherlands would be conquered by the French in November of 1792 in the war with Austria and Prussia. The French would dominate this territory, opening up the river Schlecht to navigation (in violation of existing treaties with all of the major powers), and use it to threaten the independence of Holland. It would be this threat to the Low Countries which would serve as the immediate "causus belli" for the British to break off relations with France and enter the war against the revolutionary government.

Prussia did not meet any of the requirements for inclusion in the community. It had maintained its protective and self-reliant policies until the death of Frederick the Great in 1786 , because it placed primary concern on the security threats posed by Austria, Russia, and France. 
Prussian and British cooperation in the Seven Years' War, the American Revolution, and the Napoleonic Wars can be seen as a product of the close political ties developed by Britain's Hanoverian rulers to their German countrymen. (Hubatsch, 1973)

These nations came together under British leadership during the Revolutionary and Napoleonic Wars in coalitions that were the result of long standing political-economic relationships which made wartime cooperation natural and even necessary. Table 6 : Coalitions Against France: 1792-1815

\begin{tabular}{|l|l|}
\hline Nation & Years at war with France \\
\hline Great Britain & 22 \\
Russia & $13 \frac{1 / 2}{\text { Austria }}$ \\
Spain & 13 \\
Portugal & 10 \\
Prussia & 10 \\
Ottoman Empire & 8 \\
\hline
\end{tabular}

(Source: Modelski and Modelski, 1988:238)

Table 6 shows that of Britain's major allies, only Prussia had not been a member of the trading community. The above coalitions accounted for $49 \%$ of world trade at the time of the wars, close to the $54 \%$ accounted for by the pre-war trading community. The numbers take a drop because of the loss of France and the inclusion of the smaller Prussian economy.

Britain's economic leadership carried over into the wartime operation of coalition maintenance. Britain carried on world trade, blockaded French overseas trade, signed commercial agreements opening up new areas of India and China, continued its naval supremacy, and financed to a great degree the armies of her continental coalition partners.

When Napoleon presented his Continental System in the Berlin Decrees of 1806 as an alternative system for organizing European economic relations, he was challenging the system that the British had so painstakingly put together over the previous sixty-plus years. Recalling Empress Elizabeth's statement on why trade with the British was preferred by the Russians, it is clear that these sentiments were shared by other nations. 
European governments had, by the outbreak of the war, fifty years of experience with British merchants, trade negotiators, and governments. They had watched imports and exports grow while the British balance of trade shrank. They had watched many British governments make economic policy in Europe without regard for continental ambitions. They had also seen economic policies effect British foreign policies.

[Page 90]

Journal of World-Systems Research

Was there something unique about the British trading community, or was it merely a reflection of a more general trend throughout Europe towards a more liberalized world economy. Were the British leading the system, or merely one of the herd? Examining every commercial agreement from 1740 to 1792 , makes plain a number of acts that support the hypothesis of British leadership.

If one excludes the commercial agreements between European powers and rulers in South and Southeast Asia (Great Britain 90, Netherlands 6, Portugal and France 2), and commercial agreements between European powers and North African rulers (Great Britain 6, France 6, Denmark 4, Spain 4, and the Netherlands 3), there were 28 commercial agreements between European states, Turkey, and the fledgling United States of America.

We can compare the British agreements discussed above with the treaties concluded by other European states to see if those agreements contained all of the provisions which created the British-led community.

Of the six agreements France signed with states other than Britain, only two contained an MFN clause (United States and Russia). French treaties with Sweden in 1741,Prussia in 1753 and Denmark in 1742, specifically called for preferential treatment and tariffs for French goods. All of the French treaties contained provisions for reciprocity and the rights of merchants. None of the treaties contained provisions for lowering specific tariffs on goods traded between the countries.

Of the six treaties signed by Denmark from 1740 to 1792, only two (Portugal in 1766 and Russia in 1782) contained the MFN clause. Once again, all of the treaties had provisions for reciprocity and the rights of merchants, while none of them lowered duties or tariffs on imports or exports for the parties.

Russia was the other state in Europe that concluded six agreements outside of the British community. All six of the agreements came after the landmark deal with Britain in 1766. Five of the treaties contained the MFN clause, reciprocity, and equal rights and privileges for merchants. The only treaty which did not include the MFN clause was the 1783 agreement with Turkey. Russia's agreements with France, Portugal, and the Two Sicilies in 1787 also lowered tariffs on imported goods to the level enjoyed by the British. 
Spain, Turkey, the Two Sicilies, and the United States all signed four commercial agreements during this fifty year period. In fact, if the study were to include the 1794 Jay's Treaty between the United States and Great Britain, the British trading community would have a trans-Atlantic character.

Not one of Spain's treaties with other powers contained the MFN clause or lowered tariffs. The 1786 treaty with France was confined to issues related to trade in the West Indies, and the other treaties were limited to the rights of merchants and reciprocity for the shipping of imports and exports.

Between Turkey and the Two Sicilies, only the Sicilian agreement with Russia possessed an MFN clause or a reduction of tariff levels (as stated before). The treaties of both parties were confined to merchant rights and reciprocal treatment of the parties' goods and shipping.

Only the United States, making all of its treaties between 1778 and 1792, included the MFN clause as a regular part of its commercial agreements. This may be a result of the inclusion of the United States' Free Economic Societies within a nascent epistem ic community concentrated in Britain and diffused throughout the Atlantic and European economies during the second half of the $18^{\text {th }}$ Century. It also included the standard language on merchant rights and reciprocity in every treaty. Not one of these agreements lowered tariffs specifically until Jay's Treaty of 1794 with the British.

There were other commercial agreements throughout Europe between states, and between states and city-states, but there is no evidence of a systematic attempt by any one state to create a rival community to the one purposefully created by Great Britain.

[Page 91]

Journal of World-Systems Research

\section{VII}

The conclusion that can be taken away from this study of British coalition development in the 1700s is not that we can precisely predict the coalition behavior of the global wars of 1792 to 1815; rather it is that a complete explanation of that behavior can not be limited to the immediate security interests of nations in a "nasty" anarchic system as they seek to balance the power of the state perceived to be the strongest. A more complete explanation needs to include the positive incentives in economic and political relationships developed by the British over the two generations preceding those conflicts. The British succeeded in tying together a group of states into a nascent "community" based on relative liberality and reciprocity in trading relationships. The community was founded on increased imports and exports, reduced British trade surpluses, and the formation mechanism of the 'most favored nation' clause; it resulted in tangible benefits for both Britain and its partners. The political and military actions of Revolutionary 
France, based on an intolerance of alternative forms of political and economic organization, threatened these benefits, as well as the security interests of the members of the community.

We can also make some conclusions about the role of leadership in world politics as exercised by Britain during this period. Are the hegemonic explanations of Britain's capitalist "commercial-imperial" role borne out? Or do the British actions conform closely to the Rapkin model of leadership and can it be adopted to the long cycle model of Modelski and Thompson?

First, Britain performed an important service and function for the world society during the second half of the eighteenth century. It deliberately fashioned a series of trading agreements that not only served the interests of Britain, but of its trading partners. It created an innovative solution to the trading problems of mercantilism that were being exposed by the rapid changes in Europe by the Industrial Revolution. This trading community, covering over $50 \%$ of world trade at the time, provided economic benefits that would not have been provided by the alternative trading arrangements then in place between other European states. When the actions of Revolutionary and Napoleonic France threatened this community economically, militarily, and politically, the community formed the basis for the British-led coalitions of the global war.

Second, Britain's influence and position were acquired by persuasion, not by coercion. This community, and the larger European community, was composed of states who had a long history of interactions (economic, diplomatic, and military). These states had developed hundreds of years of practice in shifting alliances, commercial arrangements, and dynastic ties that could respond to coercion (and frequently did to the British and others). The trade agreements studied here were the process of many long negotiations and searching for compatible partners. When reciprocity was lacking in one, negotiations were moved on to other states (e.g., Sweden and Russia). Empress Elizabeth's remarks about the Russian relationship and expectations of the British gove rnment and merchants embody the power of persuasion, not the power of conquest.

Third, Great Britain had definitely won the competition for first place in harnessing the effects of the Industrial Revolution. In the leading sectors of that revolution (iron manufactures and textiles) the British held a decisive advantage. (Modelski and Thompson, 1995) Braudel put the British lead over France at a 35 -year level in mechanization and textiles. (Braudel, 1984) British leadership in the military forces of global reach and commercial shipping (Modelski and Thompson, 1988) provided a stable framework behind which trade could evolve, as well as a basis for military action against potential challengers. Britain had also won the competition for ideological hegemony or intellectual leadership through the predominance of its epistemic communities of political economists, merchants, and traders. These epistemic communities set the stage for the coalition building studied here. They existed throughout Europe and the United States and they were centered in the scholarly works of the English and Scottish political economists who tutored such leaders as Pitt and Grenville. (Whiteneck, 1996) 
Fourth, the British were the role model for the other members of the community and for the future world leader of the twentieth century, the United States. The close ties between British capital and government served to create similar demands for changes in the traditional aristocratic power structures in her trading partners' domestic arrangements. Factories on the British model were started overseas and efforts were made to recruit skilled British laborers and machinists throughout the continent. The Bank of England's unique role in financing war and peace served as a role model for the establishment of future central banks. Free Trade societies were established in those countries that were a part of the community and even the intensely nationalistic Prussian government could not prevent their spreading influence in the traditional trading cities of the Baltic and North Seas. The hand-off of leadership from Britain to the United States which occurred in the global war from 1914-1945 had its roots as far back as Shelbourne's famous quote cited above, in the establishment of the Free Economic Society of Philadelphia, in Jay's Treaty of 1794, and in the British decisions on naval policy, diplomacy, and trade from 1895 to 1905 that have been pointed out by Aaron Friedberg in The Weary Titan: Britain and the Experience of Relative Decline, 1895-1905.

[Page 92]

Journal of World-Systems Research

Great Britain was able to move from a situation of mercantile leadership to one of capitalistic/industrial leadership in the only case of a world leader succeeding itself in the long cycle model. The history of the Pax Britannica of the 1800 s would be impossible without British economic, political, and diplomatic innovations in the period from 1740 to 1792 . It was those innovations which laid the groundwork for the British victories from 1792 to 1815 . The ability of the global leader to forge a coalition of nations around solutions to pressing problems of global political organization is an important characteristic of global leaders. It is as important as possessing global military forces, a dynamic economy, and a favorable geostrategic position.

Bibliography

Arrighi, Giovanni. 1994. The Long Twentieth Century, London: Verso Press.

Ashton, T.S.. 1964. The Industrial Revolution 1760-1830, New York: Oxford University Press.

Aspinall A. and E. Anthony Smith. 1957 and 1959. British Historical Documents, vols. 10 and 11, London: Eyre and Spottiswode.

Astrom, Sven-Erik. 1981. "North European Timber Exports to Great Britain 1760-1810." In Shipping, Trade and Commerce: Essays in Memory of Ralph Davis, ed. by P.L. Cottrell and D.H. Aldcroft, Leicester: Leicester University Press. 
Ayling, S.E.. 1966. The Georgian Century: 1714-1837, London: Harrap and Company.

Black, Jeremy. 1990. "Foreign Policy and the British State: 1742-1793." In British Politics and Society from Walpole to Pitt: $1742-1789$, ed. by Jeremy Black, London: MacMillan Press.

Blanning, T.C.W.. 1986. The Origins of the French Revolutionary Wars, London: Longman Group Limited.

Braudel, Fernand. 1984. The Perspective of the World: Civilization and Capitalism $15^{\text {th }}$ $18^{\text {th }}$ Century, New York: Harper and Row.

Cain, P.J. and A.G. Hopkins. 1980. "The Political Economy of British Expansion Overseas 1750-1914." Economic History Review 33: 467-489.

Chase-Dunn, Christopher. 1998. Global Formation: Structures of the World-Economy, Lanham,MD.: Rowman and Littlefield

Clendenning, P.H.. 1979. "The Background and Negotiations for the Anglo-Russian Commercial Treaty of 1766." In Great Britain and Russia in the $18^{\text {th }}$ Century: Contacts and Comparisons, ed. by A.G. Cross, Newtonville: Oriental Research Partners Press.

Cowie, L.W.. 1967. Hanoverian England, London: G. Bell and Sons Publishers.

Crafts, N.F.R.. 1983. "British Economic Growth 1700-1831: A Review of the Evidence." Economic History Review 36: 177-199.

Crouzet, F.. 1967. "England and France in the $18^{\text {th }}$ Century: A Comparative Analysis of Two Economic Growths." In The Causes of the Industrial Revolution in England, ed. by R.M. Hartwell, London: MacMillan Press.

[Page 93]

Journal of World-Systems Research

----. 1981. "The Sources of England's Wealth: Some French Views in the $18^{\text {th }}$ Century." In Shipping, Trade, and Commerce: Essays in Memory of Ralph Davis, ed. by P.L. Cottrell and D.H. Aldcroft, Leicester: Leicester University Press.

Davis, Ralph. 1966. "The Rise of Protection in England." Economic History Review 19: 306-317.

----. 1973. The Rise of the Atlantic Economies, Ithaca: Cornell University Press. 
Ehrman, John. 1962. The British Government and Commercial Negotiations with Europe 1783-1793, Cambridge: Cambridge University Press.

Fedorov, A.S.. 1979. "Russia and Britain in the $18^{\text {th }}$ Century: A Survey of Economic and Scientific Links." In Great Britain and Russia in the $18^{\text {th }}$ Century: Contacts and Comparisons, ed. by A.G>Cross, Newtonville: Oriental Research Partners Press.

Fisher, H.E.S.. 1981. "Lisbon, Its English Merchant Community and the Mediterranean in the $18^{\text {th }}$ Century." In Shipping, Trade, and Commerce: Essays in Memory of Ralph Davis, ed. by P.L. Cottrell and D.H. Aldcroft, Leicester: Leicester University Press.

Friedberg, Aaron. 1989. The Weary Titan: Britain and the Experience of Relative Decline, 1895-1905, Princeton: Princeton University Press.

Goldstein, Judith and Robert Keohane, eds.. 1993. Ideas and Foreign Policy: Beliefs, Institutions and Political Change, Ithaca: Cornell University Press.

Gregg, Pauline. 1971. Social and Economic History of Britain: 1760-1970, London: Harrap and Company.

Hall, Peter, ed.. 1989. The Political Power of Economic Ideas: Keynesianism Across Nations, Princeton: Princeton University Press.

Harlow, Vincent. 1952 and 1964. The Founding of the Second British Empire 1763-1793, vols. I and II, London: Longmans, Green, and Company.

Higgott, Richard and Andrew Cooper. 1990. "Middle Power Leadership and Coalition Building: Australia, the Cairns Group, and the Uruguay Round of Trade Negotiation," International Organization, vol. 44.

Holsti, Kalevi. 1991. Peace and War: Armed Conflicts and International Order 16481989, Cambridge: Cambridge University Press.

Hubatsch, Walther. 1973. Frederick the Great of Prissia: Absolutism and Administration, London: Thames and Hudson.

Innes, Arthur. 1985. Britain and her Rivals 1713-1789, London: A.D. Innes and Company.

Kennedy, Paul. 1987. The Rise and Fall of the Great Powers, New York: Random House.

Langford, Paul. 1989. A Polite and Commercial People: England 1727-1783, Oxford: Clarendon Press. 
[Page 94]

Journal of World-Systems Research

Laver, Michael and Norman Schofield. 1990. Multiparty Government: The Politics of Coalition in Europe, New York: Oxford University Press.

Lee, C.H.. 1986. The British Economy Since 1700, Cambridge: Cambridge University Press.

Lijphart, Arend. 1981. "Power-Sharing v. Majority Rule: Patterns of Cabinet Formation in Twenty Democracies," Government and Opposition, vol. 16.

Malcolm-Smith, E.. 1937. British Diplomacy in the $18^{\text {th }}$ Century: 1700-1789, London: William and Norgate Publishers.

Marshall, Dorothy. 1962.18 Century England, London: Camelot Press.

Modelski, George. 1987. Long Cycles in World Politics, Seattle: University of Washington Press.

Modelski, George and Sylvia Modelski, ed.. 1988. Documenting Global Leadership, Seattle: University of Washington Press.

Modelski, George and William R. Thompson. 1996. Leading Sectors and World Powers: The Co-Evolution of Global Politics and Economics, Columbia: University of South Carolina Press.

----. 1988. Seapower in Global Politics: 1494-1993, Seattle: University of Washington Press.

O'Brien, Patrick and Caglar Keyder. 1978. Economic Growth in Britain and France 1780-1914, London: George Allen and Unwin Publishers.

Parry, Clive. 1969. Consolidated Treaty Series, vols. 36-51, Dobbs Ferry: Oceana Publishing Company.

Pearson, Daniel. 1987. "The Global Economic Order of the $18^{\text {th }}$ Century." In Exploring Long Cycles, ed. by George Modelski, Boulder: Lynne Rienner Publishers.

Rapkin, David. 1986. "World Leadership." In Exploring Long Cycles, ed. by George Modelski, Boulder: Lynne-Rienner.

Rapkin, David, ed.. 1989. World Leadership and Hegemony, Boulder, Lynne-Rienner. 
Rostow, W.W.. 1975. How it all Began: Origins of the Modern World Economy, New York: McGraw-Hill Inc..

Sabatier, Paul. 1988. "An Advocacy Coalition Framework of Policy Change and the Role of Policy-Oriented Learning Therein," Policy Sciences, vol. 21.

Schroeder, Paul. 1994. The Transformation of European Politics 1763-1848, Oxford: Clarendon Press.

Schumpeter, E.B.. 1960. English Overseas Trade Statistics 1697-1808, Oxford: Clarendon Press.

Wallerstein, Immanuel. 1984. The Modern World System III, New York: Academic Press.

-----. 1980. The Modern World System II, New York: Academic Press.

Whiteneck, Daniel. 1996. "Global Leadership and Epistemic Communities: The Industrial Revolution and Liberalized Trade Agreements." Journal of World-Systems Research, vol. 2.

[Page 95]

Journal of World-Systems Research 